\title{
Misassembled During Installation
}

National Cancer Institute

\section{Source}

National Cancer Institute. Misassembled During Installation. NCI Thesaurus. Code C133721.

Problem associated with the use of the device characterized by incorrect assembly of device components, parts or constituents. 